\title{
Právo dítěte být slyšeno jako základní participační právo*
}

\section{The Right to Be Heard as a Fundamental Part of Children's Participation}

\author{
Sabina Čamdžićová**
}

\begin{abstract}
Abstrakt

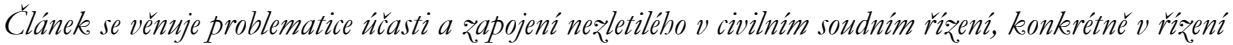
péče soudu o nezletilé, keteré se ho úzce dotýká a které má vliv na jeho budouci život. Neqletily není úcastnikem rízeni s plnou procesni zpuisobilostí a proto tato rízeni a jeho participačni práva vykazuji mnobo odlišností od rízení, kterébo se účastni pouze dospèlí.
\end{abstract}

\section{Klíčová slova}

Nezletily; participační práva; péce soudu o nezletilé; právo být slyšeno.

\begin{abstract}
The article deals with the issue of participation and involvement of a minor in civil court proceedings, specifically in family law matters, which closely affectes minor's rights and which affects his future life. Minor is not a party to the proceedings with full procedural competence and therefore these proceedings and his participation rights report many differences from adult-only proceedings.
\end{abstract}

\section{Keywords}

Child; Juvenile; Child Care Proceedings; Child's Participation Rights; Child's Right to be Heard.

\section{Úvod}

Problematika participačních práv nezletilého dítěte, tedy problematika toho, jakým způsobem má být dítě zapojeno do řízení, které se ho týká, a jaká práva má mít dítě možnost $\mathrm{v}$ řízení před soudem přímo uplatnit, je v posledních letech často skloňována. Nejčastěji v souvislosti s právem dítěte být slyšeno.

V minulosti byla Česká republika kritizována ${ }^{1}$ Výborem pro práva dítěte za to, že v praxi nedochází $\mathrm{k}$ aplikaci všech práv, která dítěti zaručuje Úmluva o právech dítěte ${ }^{2}$, ačkoli

* Tento článek vznikl za podpory prostředků poskytnutých studentskou grantovou soutěží Univerzity Palackého v Olomouci IGA Právnická fakulta 2019 „Zásahy státu do péče o dítě“ č. projektu IGA_PF_2019_014.

** Mgr. Sabina Čamdžićová, advokátní koncipientka, Toman \& Partneři, advokátní kancelář / Associate, Toman \& Partneři attorneys at law / E-mail: camdzicova@iustitia.cz

1 Srov. ZÁVĚREČNÁ DOPORUČENÍ VÝBORU OSN PRO PRÁVA DÍTĚTE přijata po projednání Třetí a čtvrté periodické zprávy České republiky o plnění závazků vyplývajících z Úmluvy o právech dítěte v Ženevě dne 31. 5. 2011.

2 Sdělení o sjednání Úmluvy o právech dítěte č. 104/1991 Sb. 
tato byla řádně implementována do vnitrostátních předpisů. To se týká mimo jiné dítěti garantovaných práv procesního charakteru, nebot' v České republice nadále mělo přetrvávat pojetí dítěte spíše jako objektu, o jehož osudu rozhodují dospělí, a nikoli jako subjektu práv, když navíc ne všechna soudní řízení umožňovala přímé zjištění názoru dítěte, a to nezávisle na jeho právním zástupci či opatrovníku. Konkrétně vyslovil Výbor znepokojení, že nedochází k výslechu dítěte v řízeních, ve kterých se rozhoduje o jejich svěření do péče či o odebrání dítěte z jeho rodinného prostředí. Od roku 2011 uběhlo již nepochybně mnoho času, kdy mimo jiné česká civilní legislativa prošla zásadními změnami v souvislosti s rekodifikací soukromého práva, která se projevila nejen prijetím tzv. nového občanského zákoníku, ale také zásadní novelizací civilně procesního práva v podobě prùjetí nového zákona upravujícího primárně tzv. nesporná řízení, tj. zákona o zvláštních řízeních soudních. V obou těchto předpisech se počítá s aktivním zapojením dítěte do řízení.

S participací dětí na řízeních, která se jich týkají, však i nadále vyvstávají problematické otázky, se kterými se obecné soudy a další subjekty musí vypořádat. Nejeden takový případ však nakonec končí až před Ústavním soudem ${ }^{3}$, který i dnes mnohdy shledá v postupech obecných soudů taková pochybení, kterými je zasaženo do ústavně zaručených práv nezletilých účastníků, potažmo v některých případech i jejich rodičů. Problematika účasti nezletilých na rrízení je tak dle mého názoru stále aktuální a vhodná k rozboru.

Dítě je třeba z pohledu soudního řízení vnímat jako plnohodnotného člověka, byt' je nezbytné kompenzovat mu neúplnou vyspělost, a je také plnohodnotný účastník řízení, at' už v jakémkoli procesním postavení - dítě může být žalobcem nebo žalovaným ve sporném řízení, může být i navrhovatelem řízení nesporného, př́ípadně účastníkem nesporného řízení, o jehož právech a povinnostech se v řízení jedná (nebo o kterém to zákon výslovně stanovî). S účastenstvím souvisí mnohé procesní nástroje a postupy. S ohledem na koncepci procesní způsobilosti, která je odvislá od způsobilosti dítěte k jednotlivému právnímu jednání, může být např́klad problematická otázka, zda dítě může samo (aniž by bylo zastoupeno) svým vlastním úkonem zahájit řízení a činit další procesní úkony.

Dostatečná míra zapojení nezletilého do rrízení je žádoucí a odpovídá také mezinárodním závazkům České republiky. Nejvíce se projevuje v právu dítěte být slyšeno ve věci, která se ho týká, nebot' se jedná nejen o prostředek zapojení dítěte, ale současně o důležitý podklad pro rozhodnutí soudu, čímž ovlivňuje také spravedlivé rozhodování a práva a povinnosti dalších účastníků, nejčastěji rodičů dítěte. Zapojení dítěte do řízení je však s ohledem na jeho neúplnou vyspělost složitější než u dospělých, protože je tř̌eba v každém jednotlivém případě zohlednit mnoho faktorů. Od rozumové a volní vyspělosti dítěte související s jeho schopností pochopit, o co se v řízení jedná, až po vyhodnocení psychického rozpoložení daného dítěte a tomu přizpůsobený způsob výslechu. To však klade rozsáhlé požadavky - a to i mimoprávní - na osobu soudce.

3 Což samozřejmě souvisí také $\mathrm{s}$ omezenou možností podat rodině $\mathrm{v}$ právních věcech dovolánî k Nejvyššímu soudu. 


\section{Nezletilé dítě jako účastník rízení}

Aby mohl nezletilý uplatňovat participační práva garantována mu právními předpisy, je nezbytné, aby se nejprve stal účastníkem rrízení, proto považuji za nezbytné zabývat se $\mathrm{v}$ tomto článku také procesní subjektivitou a procesní zpưsobilostí nezletilého alespoň v obecné rovině. Jedním ze základních (obecných) předpokladů účastenství na řízení je způsobilost být účastníkem řízení, tj. právní způsobilost být nositelem procesních práv a povinností. Tzv. procesní subjektivita je podmínkou řízení, jejíž nedostatek je neodstranitelný, a jejíž absence je důvodem pro zastavení ř́zení ${ }^{2}$ Podle \19 zákona č. 99/1963 Sb., občanský soudní řád, ve znění pozdějších předpisů (dále jen „OSŘ゙`) platí, že způsobilost být účastníkem řízení má ten, kdo má právní osobnost, jinak ten, komu ji zákon prriznává. Způsobilost být účastníkem rrízení je tak podmíněna právní osobností. Právní osobnost je dle \15 odst. 1 zákona č. 89/2012 Sb., občanský zákoník, ve znění pozdějších předpisů (dále jen „OZ“) způsobilost mít v mezích právního řádu práva a povinnosti. Právní osobnost má člověk od narození až do své smrti (\$ 23 OZ), přičemž není možné se jí vzdát ( 16 OZ). Nezletilé dítě tak nabývá způsobilosti být účastníkem ř́zení už z pouhého faktu, že je člověkem s právní osobností, kterou nabývá narozením. Je-li to v souladu s principem zájmu dítěte, je prripuštěno, aby za určitých okolností mělo právní osobnost také počaté dosud nenarozené dítě (viz \25 OZ). I nasciturus tak může mít za splnění dalších zákonných předpokladů způsobilost být účastníkem řízení.

Ve vztahu k procesním právům a povinnostem a zejména ve vztahu k jejich uplatňování je pak velmi významný pojem procesní způsobilosti, který zakotvuje $\int 20$ OSŘ, podle kterého platí, že každý může před soudem samostatně jednat v tom rozsahu, v jakém je svéprávný. Procesní způsobilostí tak rozumíme schopnost samostatně, tj. vlastními procesními úkony, před soudem jednat, přičemž její rozsah odpovídá rozsahu dosud nabyté svéprávnosti, což je právě u nezletilých účastníků řízení klíčové. Svéprávnost určuje schopnost jednotlivce právně jednat, tj. nabývat pro sebe vlastním jednáním práva a zavazovat se k povinnostem ( $\int 15$ odst. 2 OZ). Svéprávnosti se nabývá postupně, přičemž plné svéprávnosti nabývá člověk dosažením zletilosti, tj. 18 let věku (\$ 30 odst. 1 OZ). Před nabytím zletilosti lze plné svéprávnosti nabýt soudním rozhodnutím nebo uzavřením manželství (〔30 odst. 1 OZ). Ust. \31 OZ pak stanoví, že nezletilý, který nenabyl plné svéprávnosti, je způsobilý k právním jednáním co do povahy přiměřeným rozumové a volní vyspělosti nezletilých jeho věku. Způsobilosti $\mathrm{k}$ právním jednáním se tak nabývá postupně, přičemž věk dítěte hraje určité objektivní hledisko ${ }^{6}$.

4 WINTEROVÁ, Alena, Alena MACKOVÁ a kol. Civilní právo procesni - Cást prvni: Řizení nalézací. 7. vyd. Praha: Linde Praha, 2014, s. 130.

5 DOLEŽÍLEK, Jiří. In: DRÁPAL, Ljubomír, Jaroslav BUREŠ a kol. Občanský soudní rád I. $\int 1$ až 200 za. Komentár. 1. vyd. Praha: C. H. Beck, 2009, s. 108.

6 KNAPPOVÁ, Marta a Jan DVOŘÁK. In: ELIÁŠ, Karel a kol. Občanský qákonik. Velký akademický komentár, 1. svazeek, \1-487. 1. vyd. Praha: Linde Praha, 2008, s. 84. 
Primárně se svéprávnost ke konkrétnímu právnímu jednání posuzuje objektivně podle toho, jaká vyspělost obvykle odpovídá „průměrné osobě“ daného věku, nicméně jsem přesvědčená, že je třeba vždy konkrétní prrípad posoudit také dle okolností s přihlédnutím k rozumové a volní vyspělosti konkrétního dítěte ${ }^{7}$ K tomuto závěru ostatně opakovaně došel také ÚS, který uzavřel, že ,je potřeba individuálně posuzovat vyspělost nezletilého a jeho zpiisobilost uqavrít určitou smlouvu"s. Lze se však setkat i s názorem, že se jedná o hledisko čistě objektivní povahy, a je třeba primárně vycházet při posuzování přiměřenosti rozumové a volní vyspělosti ve vztahu ke všem nezletilým jeho věku s tím, že případné odchylky je třeba prokázat.

Koncept procesní zpo̊sobilosti v civilním právu je tedy postaven na odkazu do hmotného práva a závisí na míre svéprávnosti, které nezletilý dosáhnul. Zákon výslovně neupravuje, zda se má míra svéprávnosti posuzovat ve vztahu ke hmotněprávnímu jednání, o které se v ř́izení jedná, anebo zda ve vztahu k jednotlivým procesním úkonům, které může učinit účastník řízení, nicméně odborná literatura i judikatura se již shodla na tom, že rozhodující je hmotněprávní jednání. S tímto závěrem se plně ztotožňuji. Jak uvádí Š́nová ${ }^{10}$, i sám procesní předpis počítá s tím, že může nastat situace, kdy je sice nezletilý způsobilý samostatně právně jednat (a tudíž by měl být procesně způsobilý jednat samostatně před soudem), avšak předseda senátu mưže s ohledem na okolnosti případu rozhodnout, že má být nezletilý (resp. jiná osoba, která není plně svéprávná) v řízení zastoupen $^{11}$. Vychází se z toho, že procesní úkony jsou odlišné od úkonů hmotněprávních ${ }^{12}$ - složitější, a dítěti je třeba kompenzovat neúplnou vyspělost.

V zákoně č. 292/2013 Sb., o zvláštních rrízeních soudních, ve znění pozdějších předpisů (dále jen „ZŘ ``) je pak zahrnuto několik specifických řízení, ve kterých je nezletilému přiznána plná procesní způsobilost přímo ex lege, aniž by soud zkoumal zpơsobilost nezletilého $\mathrm{k}$ danému právnímu jednání ani $\mathrm{k}$ jednání před soudem. Tím je vlastně rozširrena procesní způsobilost nad rámec svéprávnosti. $V$ těchto řízeních by se tak nemělo užívat ani ust. \23 OSŘ, jehož uplatněním by byla fakticky omezena možnost nezletilého jednat před soudem samostatně. Výjimkou však může být řízení o osvojení, ve kterém lze nezletilému rodiči jmenovat opatrovníka dle $\int 23$ OŠ̌, tento však není oprávněn udělit

7 Srov. ŠíNOVÁ, Renáta. Procesní způsobilost nezletilých účastníků rízení (s přihlédnutím k právní úpravě svéprávnosti v novém občanském zákoníku). Právní roz̧bled,. Praha: C. H. Beck, 2011, č. 17, s. 617.

8 Srov. nález Ústavního soudu ze dne 8. 1. 2019, sp. zn. IV.ÚS 1639/18, ve kterém ÚS řešil otázku způsobilosti nezletilé účastnice ve věku 17 let uzavř́t smlouvu o ubytování.

9 Srov. TINTĚRA, Tomáš. In: KŘíVÁČKOVÁ, Jana, Klára HAMULÁKOVÁ a Tomáš TINTĚRA. K pojetí ćlověkea a véci v novém soukromém právu. 1. vyd. Praha: C. H. Beck, 2015, s. 14.

10 ŠíNOVÁ, Renáta. Procesní způsobilost nezletilých účastníků rrízení (s přihlédnutím k právní úpravě svéprávnosti v novém občanském zákoníku). Práuni roz̧bledy. Praha: C. H. Beck, 2011, č. 17, s. 617.

11 Tzv. „pojistka předsedy senátu“ podle $\ 23$ odst. 1 OŠ̌.

12 ŠíNOVÁ, Renáta. Procesní způsobilost nezletilých účastníkủ řízení (s přihlédnutím k právní úpravě svéprávnosti v novém občanském zákoníku). Práuni roz̧hledy, Praha: C. H. Beck, 2011, č. 17, s. 617. 
souhlas s osvojením ${ }^{13}$. Stejně tak lze uvažovat o výjimečné aplikaci pojistky předsedy senátu v př́padě nezletilého, který sice dosáhne zákonem předvídaného věku (typicky 16 let), nicméně zjevně nedosahuje takového stupně rozumové a volní vyspělosti jako průměrné osoby stanoveného věku. V takovém př́ípadě by nejspíš bylo vhodnější chránit procesní práva nezletilého prostřednictvím opatrovníka, nikoli za každou cenu trvat na procesní způsobilosti nezletilého.

Konkrétně mezi tato řízení patří řízení o povolení uzavřít manželství dle $\int 367$ a násl. ZŘS, ve kterém je přiznána plná procesní způsobilost nezletilému, který dosáhl věku 16 let a který hodlá uzavřít manželství (\367 ZŘS). Další řízení, ve kterém je nezletilému, který dosáhl věku 16 let, prriznána plná procesní svéprávnost, je ř́izení ve věcech ochrany proti domácímu násilí dle \400 a násl. ZŘS. Podle \431 odst. 2 ZǨS je pak plně procesně způsobilý nezletilý rodič v řízení o osvojení jeho dítěte. Ust. 481 odst. 2 ZŘS pak stanoví, že $\mathrm{v}$ řízení o navrácení dítěte $\mathrm{v}$ př́padě mezinárodního únosu je plně procesně způsobilý také rodič dítěte, který dosáhl věku 16 let. Třetí odstavec téhož ustanovení stanoví, že nezletilý rodič dítěte, který není plně svéprávný a nedosáhl věku 16 let, musí být $\mathrm{v}$ řízení zastoupen zákonným zástupcem, pokud soud dospěje k závěru, že jeho rozumová a volní vyspělost mu neumožňuje jednat v ř́zení samostatně. To znamená, že i rodič mladší 16 let může být v tzv. návratovém řízení teoreticky plně procesně způsobilý, pokud soud nedospěje k opačnému závěru. Z povahy věci je logické, že plná procesní způsobilost je přiznána také nezletilému v řízení o přiznání svéprávnosti a nezletilému $\mathrm{v}$ řízení o přivolení souhlasu a odvolání souhlasu zákonného zástupce k samostatnému provozování obchodního závodu nebo k jiné obdobné výdělečné činnosti (〔 469 odst. 2 Ž̌S ve spojení s \466 písm. r) a s) ZŘS).

\section{Participační práva nezletilého v civilním soudním řízení}

$\mathrm{V}$ českých překladech materiálů UNICEF dostupných na internetu ${ }^{14}$ jsou „,participation rights“, která mají být vedle dalších práv dítěti garantována, přeložena jako právo na začlenění nebo také jako právo na zapojení do společnosti, přičemž konkrétní články Úmluvy o právech dítěte, kterými mají být tato práva garantována, jsou uvedeny heslem: „Právo na začlenèní: blas, keterý je slyšet" "15.

Takovou definici lze vlastně převést i do civilního soudní řízení. Podstatou toho, že byla i nezletilým přiznána procesní participační práva, je to, že je dítě do řízení prrímo zapojeno a má možnost ovlivnit svými vlastními úkony jeho průběh a výsledek, protože, jak opakovaně uvedl Ústavní soud, platí, že „ditě (účastník rízeni) neni poubým objektem rozhodováni a neni ani di̛vod upirat mu (jako účastniku rízeni) právo být prítomen jeho projednávané vèci

\footnotetext{
13 SVOBODA, Karel, Šárka TLÁŠKOVÁ, David VLÁČIL, Jiří LEVÝ, Miroslav HROMADA a kol. Zákoon o zulástních rízeních soudních. Komentár. 1. vyd. Praha: C. H. Beck, 2015, s 696.

14 Https://www.unicef.cz/aktualne/82292-umluva-o-pravech-ditete

15 Https://www.unicef.cz/odkazove_zdroje_textove_materialy/prava_deti/participace.pdf
} 
(čl. 38 odst. 2 Listiny, čl. 12 Úmluvy o právech ditéte, čl. 3 Evropské úmluvy o výkonu práv dètí, $\int 100$ odst. 3, o. s. r. . \ 867 občanskébo zákoníku)." 16

Participační práva dítěte $\mathrm{v}$ řízení slouží tedy k zapojení dítěte do procesu rozhodování, dítěti poskytují větší vliv na rozhodovací činnost. Participace dítěte na řízení je možná za splnění několika podmínek ${ }^{17}$. První z nich je rozumová schopnost dítěte utvořit si vlastní názory. Další podmínkou je věk dítěte, který však nelze chápat jako klíčové objektivní hledisko ${ }^{18}$. To lze ostatně dovodit i ze skutečnosti, že ani Úmluva o právech dítěte, ani Evropská úmluva o výkonu práv dětí ${ }^{19}$ nespojují práva dítěte s žádnou věkovou hranicí. Poslední podmínkou je dosažení určitého stupně zralosti dítěte, tj. schopnost dítěte porozumět tomu, co se v řízení zrovna děje, v takovém rozsahu, aby bylo schopno nejen pochopit situaci, ale také vyhodnotit možné důsledky vlastních rozhodnutí do budoucna, prípadně také vyhodnotit rozhodnutí dalších osob, zejména rodičủ nebo orgánư ${ }^{20}$.

Dá se říci, že hovořit o participačních právech dětí je fenoménem posledních let, který nepochybněsouvisís politicko-společenskýmizměnamivespolečnosti.Zaminuléhorežimunebylo zapojení nezletilého do procesu rozhodování o jeho právech a povinnostech považováno za nutné, protože v duchu socialistické ideologie měla probíhat výchova dětí ve prospěch společnosti a současně dle zákona o rodině ${ }^{21}$; platilo, že „o výchovu dětí pečují v nerozlučné jednotě rodiče, stát a společenské organizace, zejména Československý svaz mládeže a jeho pionýrská organizace" (\$ 30). Je zřejmé, že participace nezletilého se s takovými principy úplně neslučuje. Spolu se změnou politického režimu došlo samozřejmě k upuštění od ideologického smýšlení v duchu socialismu a výchovy dětí ku prospěchu společnosti, nicméně nelze očekávat, že všichni změní své myšlení a přístupy ze dne na den. Paternalistický př́stup k dětem ${ }^{22}$ je tak v naší společnosti dlouhá léta zakořeněný a projevuje se také v př́istupu úřadů, vč. orgánu sociálně právní ochrany dětí (dále jen „OSPOD“) a soudů. Považuji proto za naprosto přirozený vývoj, že k obecnému přijetí myšlenky, že i dítě je plnohodnotným účastníkem řízení, kterému náleží všechna práva jako ostatním účastníkům, dochází až v posledních letech. V této souvislosti je nutné pozitivně vyzdvihnout judikatorní činnost Ústavního soudu, která právo dítěte podílet se na rozhodování o své věci plně respektuje.

16 Srov. nález Ústavního soudu ze dne 19. 6. 2018, sp. zn. III.ÚS 1265/16.

17 PTÁČEK, Lubomír. In: MELZER, Filip, Petr TÉGL a kol. Občanský qákoník - velký komentár. Svaz̨ek IV. Díl 2. \ 794-975. 1. vyd. Praha: Leges, s. r. o., 2016, s. 1413.

18 Ibid.

19 Sdělení Ministerstva zahraničních věcí č. 54/2001 Sb. m. s.

20 PTÁČEK, Lubomír. In: MELZER, Filip, Petr TÉGL a kol. Občanský zákoník - velký komentár. Svazek IV.

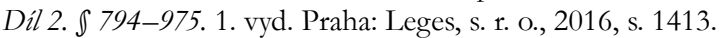

21 Zákon č. 94/1963 Sb., o rodině, v původním znění.

22 HOFSNEIDEROVÁ, Anna. Participační práva dětí mladších 15 let v řízení o činu jinak trestném. In: CIRBUSOVÁ, Martina a Zdeněk KAPITÁN (eds.). Tradiční jevy a nové tendence v oblasti ochrany práv dètí praxe participačnich práv a kyberšikana. Brno: Tribun EU, 2015, s. 59. 


\section{Právo dítěte být slyšeno jako základní participační právo}

Jedním ze základních a nejspíš i nejdůležitějších procesních participačních práv dítěte je právo dítěte být slyšeno. Realizace práva být slyšeno umožňuje dítěti vyjádřit svůj názor či přání ve věci, která se ho týká, a to způsobem, který odpovídá jeho rozumové a volní vyspělosti. Jedná se tak o faktickou možnost účastnit se řízení, aniž by na tento úkon byly kladeny jakékoli speciální procesní formální požadavky. Od určitého věku (nebo lépe řečeno stadia vývoje) je tak schopno ho využít téměř každé dítě, aniž by potřebovalo jakékoli znalosti (v konečném důsledku dítě nemusí umět ani číst a psát, aby bylo schopno se vyjádřit). Právu dítěte být slyšeno, které chápu jako procesní zpơsob zjišt'ování názoru nezletilého, je proto níže v tomto článku věnován široký prostor.

Je nezbytné také úvodem konstatovat, že právo dítěte být slyšeno je skutečně právem, nikoli povinností. Součástí participačních práv dítěte je také právo volby zůstat pasivní a na řízení se nikterak nepodílet. Ačkoli je právo dítěte být slyšeno jeden z vưdčích principů civilního procesu, kterého se nezletilé dítě účastní, existují výjimky, kdy jej soud nemusí $\mathrm{v}$ řízení aplikovat, tedy kdy nemusí být dítě slyšeno. Jednak jsou to př́ípady, kdy je s ohledem na osobu dítěte ${ }^{23}$ (at' už s ohledem na rozumovou a volní vyspělost anebo s ohledem na jiné okolnosti př́padu) efektivnější výslech prostřednictvím jiné osoby - např. prostřednictvím OSPOD nebo prostřednictvím jiné osoby (\100 odst. 3 OSŘ, \ 867 odst. 2 OZ). Soud je také oprávněn od slyšení dítěte upustit úplně. Mưže tak učinit v situaci ${ }^{24}, \mathrm{kdy}$ je z aktuální procesní situace zřejmý nedostatek dalších důkazů, které by soudu umožnily ve věci rozhodnout tak, aby se rozhodnutí jakkoli dotklo práv dítěte. Výslech dítěte by v takovém př́padě byl nadbytečným.

Soud je oprávněn opustit od slyšení dítěte také v situaci, kdy by výslech byl v rozporu s nejlepším zájmem dítěte. To mohou být situace, kdy by výslech mohl pro dítě znamenat nepřiměřenou psychickou zátěž. V této souvislosti je tak třeba dát za pravdu Ústavnímu soudu, který uzavřel, že ,[a]čkoli je výslech ditète pred soudem mnohdy důležitou součástí zjišstováni podkladu pro spravedlivé rozhodnutí [...], nemưže a nesmi predstavovat absolutni povinnost, ale naopak musi být predmètem pećlivého posouzeni [...] “. ${ }^{25}$

\subsection{Právo dítěte být slyšeno v mezinárodních předpisech}

Právo dítěte být slyšeno v řízení, které se týká jeho práv a povinností, je mu garantováno jak na mezinárodní, tak národní úrovni. Podle čl. 12 odst. 1 Úmluvy o právech

23 Srov. např. nález Ústavního soudu ze dne 30. 5. 2014, sp. zn. I ÚS 1506/13, kde ÚS konstatoval, že „v daném prípadě, zejména sobledem na nízký věk dítéte [6 let - pozn. aut.] a jeho hluboké citové vazby kobèma rodičum, tak ani Ústavni soud nepovažuje procesni výslech nezletilé préd soudem za vhodný a potrebny".

24 PTÁČEK, Lubomír. In: MELZER, Filip, Petr TÉGL a kol. Občanský quákoník - velký komentár. Svaz̨ek IV. Dil 2. \ 794-975. 1. vyd. Praha: Leges, s. r. o., 2016, s. 1414.

25 Srov. nález Ústavního soudu ze dne 12. 9. 2014, sp. zn. I. ÚS 2643/2013. 
dítěte musí stát zabezpečit dítěti, které je schopno formulovat své vlastní názory, právo tyto názory svobodně vyjadřovat ve všech záležitostech, které se jej dotýkají, přičemž se názorům dítěte musí věnovat patřičná pozornost odpovídající jeho věku a vyspělosti. Toto právo má být realizováno zejména poskytnutím možnosti být slyšeno $\mathrm{v}$ každém soudním nebo správním řízení, které se jej dotýká, a to bud' přímým slyšením dítěte, anebo prostřednictvím zástupce nebo prŕslušného orgánu, vše v souladu s vnitrostátními procesními předpisy (čl. 12 odst. 2 Úmluvy).

Evropská úmluva o výkonu práv dětí pak obsahuje ustanovení, která mají dětem zaručovat možnost vykonávat svá práva ve svém nejlepším zájmu, za tímto účelem jim poskytnout procesní práva a usnadnit jejich výkon tím, že bude zabezpečeno, aby děti, přímo nebo prostřednictvím jiných osob nebo orgánů, získaly př́slušné informace o soudních řízeních, která se jich týkají, a mohly se jich účastnit ${ }^{26}$. Článek 3 EÚVPD stanoví, že „díté, které má podle vnitrostátnich predpisu dostatečnou schopnost chápat situaci, bude mit v soudním rízeni, k.teré se jej týká, zaručena následujici práva nebo bude mit možnost se téchto práv domáhat, pričemž. mezi tato práva patrí právo dostávat príslušné informace, právo být konzultováno a moci vyjádrit svioj názor, a právo být informováno o možných dìsledcich vyhovéní jeho názoru a o možných duisledcich jakéhokoliv roz̧hodnutí."V souladu s článkem 6 EÚVPD musí soudní orgán před tím, než rozhodne v řízení, které se týká dítěte, primárně posoudit, zda má dostatečné informace, aby mohl rozhodnout dle nejlepšího zájmu dítěte, a dále, což je rozhodující v kontextu tohoto článku, pokud se podle vnitrostátních předpisů má zato, že dítě dostatečně chápe, o co se v řízení jedná, zabezpečit, aby dítě obdrželo všechny příslušné informace, ve vhodných př́padech dítě vyslechnout, je-li to třeba, neveřejně, bud' přímo nebo prostřednictvím jiných osob nebo orgánů způsobem, který je přiměřený chápání dítěte, pokud to není ve zjevném rozporu s nejlepšími zájmy dítěte, umožnit dítěti vyjádřit svůj názor; a v neposlední řadě vzít názor dítěte náležitě v úvahu.

Právo dítěte být slyšeno rovněž představuje jeden z principů, na kterých má stát řízení týkající se dítěte podle Pokynů Výboru ministrů Rady Evropy o justici vstřícné k dětem² které i jako nezávazné soft law představují cenný zdroj práva, pokud jde o postavení nezletilých $\mathrm{v}$ soudních řízeních. Tento praktický nástroj mimo jiné stanoví, že vyjádření stanoviska je právem dítěte, nikoli jeho povinností ${ }^{28}$. Dítě by mělo mít možnost tohoto práva využít, kdykoli projeví vưli být slyšeno, a na jeho stanovisko by pak měl

26 KOVÁČOVÁ, Anna a Ondřej SPÁČIL. Slyšení dítěte v rámci rodinné mediace. Práuní roz̧bledy, 2014, roč. 21 , č. 10 , s. 353-358.

27 Pokyny Výboru ministrů Rady Evropy o justici vstřícné $\mathrm{k}$ dětem (Guidlines of the Committee of Ministers of the Council of Europe on child-friendly justice), přijaté Výborem ministrů Rady Evropy dne 17. 11. 2010, a důvodová zpráva. Dostupné z: https://rm.coe.int/16804ba0fb [cit. 10. 12. 2020].

28 ŠIMÁČKOVÁ, Kateřina a Kristýna MOLKOVÁ FOUKALOVÁ. Právo dítěte účastnit se soudního řízení jako jedno z participačních práv dětí pohledem judikatury Ústavního soudu. In: CIRBUSOVÁ, Martina a Zdeněk KAPITÁN (eds.). Tradiční jevy a nové tendence v oblasti ocbrany práv dètí - praxe participačních práv a kyberšikana. Brno: Tribun EU, 2015, s. 78 a 80. 
být brán patřičný zřetel odpovídající jeho věku a úrovni. Dítěti má být vysvětleno, jakou váhu jeho stanovisko má a také to, že mu nakonec nemusí být vyhověno a následně zejména $\mathrm{v}$ těchto př́padech ( $\mathrm{kdy}$ přání dítěte soud nevyhovî) by mu mělo být dostatečně srozumitelně vysvětleno i konečné rozhodnutí, vč. odůvodnění ${ }^{29}$.

Výše uvedené mezinárodní prameny pak shodně zavazují státy ve své jurisdikci k tomu, aby zaručily dítěti možnost účastnit se všech řízení, která se jej týkají, a to takovým zpưsobem, který odpovídá schopnostem dítěte pochopit, o co se v řízení jedná, to znamená takovým zpơsobem, který odpovídá vyspělosti dítěte. Je tak plně respektováno, že dítě se vyvijí postupně, a vzhledem ke svému věku a rozumové vyspělosti se tak postupně mění (rozšiřuje) schopnost dítěte samostatně v řízení vystupovat, vč. schopnosti formulovat a vyjádřit svůj názor. Posouzení, zda je dítě schopno náležitě pochopit situaci, je pak nezbytné činit vždy ve vztahu ke konkrétnímu dítěti, takový závěr nelze objektivizovat pouze na základě věku.

Z výše uvedeného pak jednoznačně vyplývá, že státy jsou povinny zajistit, aby v průběhu řízení, kterého se účastní dítě, které dostatečně chápe situaci, aniž by byla stanovena konkrétní věková hranice, mohlo vyjádřit svůj názor, aby také mohlo uplatnit své právo být ve vhodných případech vyslechnuto a aby dítěti byly poskytovány relevantní informace způsobem odpovídajícím rozumové vyspělosti konkrétního dítěte, tak aby bylo schopno vytvořit si na věc názor, a také aby mohlo dostatečně pochopit, o co se v řízení jedná a jaké pro něj bude mít řízení důsledky.

\subsection{Právní rámec práva dítěte být slyšeno v české úpravě}

Zákonný rámec práva dítěte být slyšeno v českém civilním soudním řízení představují zejména ust. \100 odst. 3 OSŘ, ust. \20 odst. 4 Ž̌̉ a ust. \867 OZ.

Podle \ 100 odst. 3 OSŘ platí, že „V ř́zení, jehož účastnikem je nezletilé dítè, které je schopno formulovat své názory, soud postupuje tak, aby byl zjistèn jeho názor ve véci. Názor nezletilého dítète soud zjistí výslechem dítète. Názor ditète může soud ve výjimečných prípadech zjistit též prostrednictvím jeho zástupce, znaleckého posudku nebo prìslušnébo orgánu sociálnè-právni ochrany dètí. Výslech ditète mưž̀ soud provést $i$ bez prítomnosti dalšich osob, lze-li očekávat, že by jejich pritomnost mobla ovlivnit ditè tak, že by nevyjádrülo svìj skutečný názor; prítomnost divvěrnike ditète, který není jeho zákonným zástupcem a o jehož účast u výslechu ditě požádá, mưže soud vyloučit jen tehdy, je-li jeho prítomnosti mařen účel výslechu. K názoru ditète soud približi s priblédnutím ke jeho věku a rozumové vyspèlosti."ZŘS dále doplňuje, že „v rízení, jehož účastnikem je nezletilý, který je schopen pochopit situaci, soud postupuje tak, aby nezletily dostal potrebné informace o soudním rízeni a byl informován o možných duisledcich vyhovéni svému názoru i dìsledcich soudního roz̧hodnuti." ZŘS tak jako lex specialis k OSŘ výslovně stanovuje povinnost soudu poskytnout dítěti potřebné informace o daném řízení a důsledcích jednání nezletilého dítěte $\mathrm{v}$ průběhu tohoto rízení.

29 Ibid., s. 80. 
V řízeních vedených dle ZŘS tak zákonodárce zvýšil ochranu participačních práv dítěte výslovným zakotvením podrobnější poučovací povinnosti soudu. Není však pochyb o tom, že i v řízeních, na které se ZŘS nevztahuje, čili primárně v tzv. sporných řízeních, má soud vưči nezletilému dítěti určitě pozitivní povinnosti. Autoři komentářre ${ }^{30} \mathrm{k}$ tomu dále uvádějí, že nezletilý nepochybně požívá zvýšené míry procesní ochrany i ve sporných řízeních, když ust. \100 odst. 3 OSŘ zůstalo zachováno i poté, co řízení ve věcech péče soudu o nezletilé byla přenesena do ZŘS. Výslovně to stanoví také $\int 867$ OZ, který ve svém prvním odstavci stanoví, že „prè rozhodnutim, které se dotýká zájmu dítète, poskytne soud ditèti potrebné informace, aby si moblo vytvorit vlastni názor a tento sdèlit". Druhý odstavec tohoto ustanovení dále upravuje situace, kdy se dítě není schopno na ř́zení samo přímo podílet a také stanovuje právní domněnku, že dítě starší 12 let je schopno informaci přijmout, vytvořit si vlastní názor a tento sdělit.

Česká právní úprava tak obsahuje komplexní, byt' v určitém ohledu zbytečně roztř́šstěnou ${ }^{31}$, právní úpravu zajišt'ující úplné provedení čl. 12 Úmluvy a také EÚVPD v civilním soudním řízení, když je ve všech řízeních, která se týkají dítěte, kladen dưraz na přímé slyšení nezletilého, je-li to s ohledem na jeho věk a rozumovou vyspělost možné a vhodné, resp. je-li to v zájmu nezletilého, aby bylo v řízení vyslechnuto. Lze uzavrrít, že do dovršení dvanáctého roku dítěte má soud individuálně posoudit u každého dítěte, zda je schopno formulovat své názory, přičemž jejich obsah nebo hodnota by však patrně neměly být rozhodující pro uplatnění práva být slyšeno jako takového. Je-li dítě schopno svůj názor formulovat, má dále právo, aby mu soud poskytnul veškeré relevantní informace, dítě má také právo se dotázat na př́ipadné nejasnosti, právo svůj názor vyjádřit a současně být poučeno o všech důsledcích spojených s vyjádřeným názorem, v neposlední radě má dítě také právo na informaci, proč bylo či nebylo jeho názoru (přánî) vyhověno a jaké důsledky pro něj bude mít rozhodnutí ve věci. Soud je povinen aktivně jednat tak, aby dítě mohlo být přiměřeně svému věku a rozumové úrovni v největší možné míře zapojeno do řízení. Př́mý výslech dítěte může být $\mathrm{v}$ př́ipadech, kdy dítě není schopno svůj názor formulovat, nahrazen výslechem třetí osoby, která je schopna hájit zájmy dítěte a její vlastní zájmy nejsou v rozporu se zájmy dítěte (viz \867 odst. 2 OZ a \100 odst. 1 OSŘ). Upustit od zjišt'ování názoru dítěte soud může jen zcela výjimečně, pokud by to bylo v rozporu s jeho zájmem.

Důležité je konstatovat, že právo dítěte být slyšeno (a obecně právo uplatňovat svá participační práva) musí být vykládáno v kontextu čl. 38 odst. 2 Listiny základních práv a svobod $^{32}$ (dále jen „LZPS“), tedy že každý má mimo jiné právo na to, aby byl přítomen

30 SVOBODA, Karel, Petr SMOLÍK, Jiří LEVÝ, Renáta ŠÍNOVÁ a kol. Občanský soudní rád. Komentár. 1. vyd. Praha: C. H. Beck, 2013, s. 343.

31 Mám za to, že by bylo vhodnější, aby byla právní úprava koncentrována do jediného obecně platného předpisu, tak aby byla použitelná ve stejném rozsahu na všechna ř́zení dotýkající se nezletilého dítěte.

32 Usnesení předsednictva České národní rady č. 2/1993 Sb., o vyhlášení Listiny základních práv a svobod jako součásti ústavního pořádku České republiky, ve znění pozdějších předpisů. 
při projednání své věci a aby se mohl vyjádřit ke všem prováděným důkazům, nebot' dítě i přes svou neúplnou vyspělost je úplným účastníkem řízení, kterému náležitý veškerá práva a povinnosti jako dospělým účastníkům řízení. Nedostatek věku a rozumové vyspělosti je dítěti třeba kompenzovat procesními nástroji, a to právě s ohledem na potřeby daného konkrétního dítěte. Dítěti a jeho právům je třeba poskytnout zvýšenou ochranu, aby samo sobě nemohlo pro nedostatečnou vyspělost uškodit. Na druhou stranu zvýšená ochrana nerovná se vyloučení možnosti aktivně se na řízení podílet jen proto, že dítě je dítě. Jak opakovaně konstatoval Ústavní soud, „i ditě má právo být duiležitým subjektem a účastnikem rízeni, nikoliv jen objektem ochrany a pasivnim pozorovatelem rozhodování o své zálę̌itosti" “33.

\subsection{Proces a průběh zjišt'ování názoru nezletilého}

Z výše uvedeného pak jednoznačně vyplývá, že účastní-li se řízení dítě, které je schopno posoudit situaci a formulovat své názory, je soud povinen takové dítě vyslechnout.

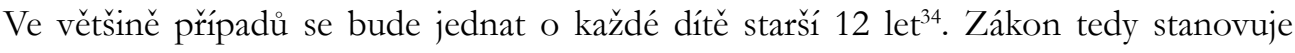
pozitivní povinnost soudu postupovat $\mathrm{v}$ řízení tak, aby byl zjištěn názor nezletilého, který je schopen formulovat své názory. Soudce by měl primárně vyslechnout dítě sám prímo (tzv. přímé slyšení dítěte). Ve výjimečných př́ípadech je možné zjistit názor dítěte prostřednictvím jeho zástupce, znaleckého posudku nebo prríslušného orgánu sociálně-právní ochrany dětí. Soud postupuje tak, aby nezletilý dostal potřebné informace o soudním řízení a byl informován možných důsledcích vyhovění svému názoru i důsledcích soudního rozhodnutí. Postup soudu musí být tedy takový, aby nezletilý byl schopen pochopit svou situaci a všechny důsledky probíhajícího řízení, vč. důsledků toho, co v řízení (ne)řrekne. Podstatné je také to, že dítě má právo vyjádřit svůj názor svobodně ${ }^{35}$, tedy v největší možné míře bez ovlivnění jinými osobami.

Právem dítěte být slyšeno se ve své judikatuře opakovaně zabýval také Ústavní soud ČR. V jednom ze svých aktuálních rozhodnutíi ${ }^{36}$ pak Ústavní soud formuloval názor, že je to soud, kdo je odpovědný za to, aby ke zjištění názoru dítěte došlo v souladu se zákonem. Ústavní soud v citovaném rozhodnutí dovodil, že součástí práva být slyšeno je nejenom samotné právo dítěte vyjádřit se v řizení, ale také právo na všechny relevantní informace. Ústavní soud tak konstatoval, že ,právo dítète být slyšeno v rízení, které se jej týká, ve smyslu čl. 12 Úmluvy o právech dítéte se neomezuje na poubé zjišténi názoru dítěte na projednávanou

33 Srov. např̀. nález Ústavní soudu ze dne 2. 4. 2009, sp. zn. II. ÚS 1945/2008, nebo nález Ústavního soudu ze dne 8. 10. 2018, sp. zn. II. ÚS 725/18.

34 HRUŠÁKOVÁ, Milana, Zdeňka KRÁLÍČKOVÁ, Lenka WESTPHALOVÁ a kol. Občanský zákoník II. Rodinné právo (』 655-975). 1. vyd. Praha: C. H. Beck, 2014, 1392 s.

35 PTÁČEK, Lubomír. In: MELZER, Filip, Petr TÉGL a kol. Občanský qákoník-velký komentár. Svazek IV. Dil 2. \ 794-975. 1. vyd. Praha: Leges, s. r. o., 2016, s. 1414.

36 Nález Ústavního soudu ze dne 8. 10. 2018, sp. zn. II. ÚS 725/18. 
záležitost, ale zahrnuje také dalši komunikaci s ditètem a informováni jej o rízení, věetnè toho, jak nakonec bylo rozhodnuto $v$ záležitosti ditéte a jak byl zoblednèn jeho zjištèný názor (vyjádrilo-li jej dité). Za dodrženi tohoto práva odpovidá soud. Je-li ditě zpiosobilé být v rízení vyslechnuto primo soudem a neni-li to rozporné s jeho nejlepsim zájmem, pak by to mèl být rouněž prímo soud, kdo dotčenému dítèti prìstupnou formou vysvětlí, jak v jeho záležitosti bylo roz̧odnuto a jak pritom byl zoblednèn jeho názor."

Ústavní soud tak tímto rozhodnutím na rámec zákona také definoval pozitivní povinnost soudu vysvětlit dítěti způsobem odpovídajícím jeho potřebám a schopnostem i to, jakým způsobem ve věci rozhodl a proč. Ústavní soud tak učinil ve výrokové části, jedná se tak o závaznou část rozhodnutí. Pokud tedy soud takto např́iště neučiní, dopouští se dle Ústavního soudu porušování ústavně zaručených práv dítěte. S tímto závěrem vyslovil nesouhlas soudce Vojtěch Šimíček ve svém odlišném stanovisku, když uvádí, že je samozřejmě správně, pokud soudce dítěti výsledek řízení vysvětlí, nicméně nelze bez dalšího říci, že pokaždé, kdy tak neučiní, dopouští se porušení ústavně zaručených práv.

Není pochyb o tom, že má dítě právo vědět, jak řízení skončilo a zda a jakým způsobem byl zohledněn jeho názor a př́padně proč nebyl. Na druhou stranu nejsem přesvědčena, že za všech okolností by to měl být soud, kdo dítěti výsledek řízení sdělí, resp. zda je třeba takovou povinnost generálně závazně dotvářet. Ne vždy se např́íklad soudci musí povést navázat s dítětem vztah důvěry. $V$ takovém prrípadě by bylo dle mého názoru spíše kontraproduktivní, aby soud dítěti vysvětloval, jak rozhodl a proč tak rozhodl, zejména v př́padech, kdy rozhodne odlišně od jeho přání.

Pokud jde o samotný průběh zjišt’ování názoru nezletilého, tak v zásadě není třeba dodržení formálních postupů, které jsou neodmyslitelné při výslechu dospělých účastníků řízení nebo svědků. Průběh slyšení nezletilého by měl vždy odpovídat potřebám daného konkrétního dítěte. Slyšení dítěte může probíhat i mimo jednání, a také mimo soudní sín (at' už ve speciálních výslechových místnostech pro nezletilé nebo např́íklad v kanceláři soudce). Pokud lze očekávat, že by přítomnost dalších osob mohla ovlivnit dítě tak, že by nevyjádřilo svůj skutečný názor, lze prítomnost takových osob vyloučit, typicky se bude jednat např́klad o rodiče dítěte. Dítě má však právo na přítomnost svého důvěrníka, kterým může být třeba třídní učitelka nebo jiná osoba, ke které má dítě důvěru. Důvěrníkem nesmí být ten, jehož zájmy mohou být v kolizi se zájmy nezletilého. Samotný výslech má pak probíhat komplexně, zejména prostřednictvím nepř́imých otázek, je nutné vyvarovat se zavádějících otázek typu „U koho bys chtěl/a bydlet? ${ }^{\text {‘37 }} \mathrm{V}$ průběhu výslechu je proto úkolem soudu mimo jiné dítěti vysvětlit právní stav a následky možného rozhodnutí i z dlouhodobého hlediska - dá se chápat jako velmi široká poučovací povinnost soudu, související s povinností chránit práva nezletilého.

37 ROGALEWICZOVÁ, Romana. Možnosti aktivního zapojení dítěte do řízení. Právní roz̧hledy, 2018, roč. 25 , č. 8 , s. 267-275. 
Soud je povinen věnovat patřičnou pozornost informacím získaným od dítěte, nebot' je to soud, kdo je nakonec dává do kontextu celého řízení a kdo je musí vyhodnotit.

Názorem zjištěným od dítěte soudce není vázán, nebot' v souladu s čl. 3 Úmluvy musí být rozhodnutí dotýkající se práv dítěte primárně v souladu s jeho zájmy tak, aby bylo dosaženo blaha dítěte. Soudce by proto měl i na tuto skutečnost dítě upozornit a vysvětlit mu, že každé jeho přání nemusí vždy odpovídat jeho zájmům. To pak také souvisí s popsanou povinností vysvětlit dítěti, jak bylo v ř́zení rozhodnuto a proč.

Ze všeho, co bylo výše uvedeno, jednoznačně vyplývá, že v souvislosti s vedením výslechu nezletilého, resp. v souvislosti se zjišt'ováním názoru nezletilého, je na soudce, kteří vedou dané rrízení, kterého se účastní nezletilé dítě, kladeno mnoho požadavků. V prvé řadě by to měl být soudce, kdo posoudí, zda je konkrétní dítě schopno formulovat svůj názor a zda by měl přistoupit k jeho výslechu. Je to také soudce, kdo musí posoudit, zda je v zájmu nezletilého, který je schopen formulovat svůj názor, aby byl slyšen př́mo soudem, či zda má být spíše zjištěn názor nezletilého nepřímo, a v neposlední řadě je to pak také soudce, kdo musí výslech nezletilého efektivně provést, a jak vyplývá mimo jiné z posledně citovaného judikátu ústavního soudu, jehož výrok je precedenční; soudce je také povinen poskytnout dítěti veškeré informace o řízení, o jeho průběhu i výsledku. V duchu citovaného rozhodnutí Ústavního soudu je to soudce, kdo je odpovědný za splnění všeho, co bylo výše uvedeno.

Aby soudce dostál všem požadavkům, měl by být za všech okolností schopen dostatečné empatie a citlivého prŕstupu k dítěti. Soudce by měl být schopen posoudit také psychický stav dítěte a jeho náladu. Každé dítě je ale jiné, a to minimálně s ohledem na věk a stupeň rozumové vyspělosti, ale také s ohledem na psychický stav a možná traumata, která dítě může v souvislosti s řízením prožívat. Soudce by proto měl také znát různé způsoby vedení rozhovoru a mít nepochybně aspoň základní znalosti psychologických/pedagogických znalostí (např. vývojová specifika dle věkových skupin).

\subsection{Návrh de lege ferenda}

Nesmíme zapomínat, že soudce je „jenom“ právník. Je nepochybné, že dítě je třeba chránit a přitom mu současně garantovat jeho procesní práva, je však otázkou, zda je opravdu správné řešení, aby odpovědnost opravdu plném rozsahu ležela na soudu, resp. potažmo na konkrétním soudci. V tomto směru bych navrhovala spíše zajištění efektivního zastoupení nezletilého dítěte. Díky inspiraci v zahraničních úpravách si troufám tvrdit, že dobrým řešení de lege ferenda by tak mohlo být zavedení samostatné nové funkce (profese) kolizních opatrovníků dětí v rúzení. 
Podle $\int 158$ německého zákona o řízeních ve věcech rodinně právních a v záležitostech nesporného soudnictvi ${ }^{38}$ může soud dítěti jmenovat opatrovníka - pomocníka v řízení, který by měl mít právní nebo psychologické vzdělání a v řízení má jedinou roli, a sice pomáhat dítěti v ř́zení ${ }^{39}$.

Podobné pojetí zastoupení nezletilého dítěte v soudním řízení zastává také australský právní řád. V rodinně právním řízení může soudce ze své iniciativy, případně k návrhu k tomu oprávněných osob, nezletilému dítěti ustanovit (na všech procesních stranách) nezávislého právního zástupce ${ }^{40}$. Úkolem nezávislého právního zástupce dítěte je chránit nejlepší zájmy dítěte, informovat dítě o postupu v řízení, zjišt'ovat jeho názor a ten reprezentovat v soudním řízení. Zástupce může také navrhovat důkazy a klást otázky účastníkům řízení. Má také zajištovat, aby řízení představovalo pro dítě co nejmenší trauma. Nezávislý právní zástupce dítěte musí mít právní vzdělání, čímž je garantována také odborná stránka zastoupení dítěte v řízení před soudem ${ }^{41}$.

Také v Izraeli funguje institut zástupců dítěte (,guardian ad litem“422), kteří jsou organizováni ministerstvem spravedlnosti a jsou mu současně odpovědni ze své činnosti. Na něm vzniklo oddělení právní pomoci, jehož součástí jsou také zástupci dítěte. V řízení, ve kterém se upravují poměry dítěte, je dítěti zástupce soudem jmenován v př́padě, že se jeho rodiče na budoucím uspořádání neshodnou. Tato úprava byla v Izraeli přijata po přistoupení tohoto státu k Úmluvě v roce 1991, což zdejší justici vedlo k povinnosti vyložit některé právní pojmy. K novelizaci zdejší úpravy tak vedla Úmluva, která je závazná i pro Českou republiku, což mě ubezpečuje v závěru, že by podobná úprava fungovala i v českém prostředí. Výsledkem bylo přijetí úpravy, která soudcům umožňuje jmenovat dítěti $\mathrm{v}$ rodinných řízeních zástupce ${ }^{43}$. Jak uvedl ve svém př́spěvku na konferenci Children's Rights and Interests ISFL Regional Conference v prosinci 2019 advokát Eytan Lipskier, který působí také jako zástupce nezletilých před soudy, v izraelské soudní praxi se stále více ukazuje, že právě institut nezávislého zastoupení dítěte je klíčem k plné

38 Gesetz über das Verfahren in Familiensachen und in den Angelegenheiten der freiwilligen Gerichtsbarkeit, zákon o řízení ve věcech rodinněprávních a v záležitostech nesporného soudnictví, ze dne 17. 12. 2008 (BGBl. I s. 2586, 2587 ff), ve znění pozdějších předpisů. Dostupné z: https://www.gesetze-im-internet. de/famfg/BJNR258700008.html [cit. 7. 3. 2021].

39 ŠÍNOVÁ, Renata a kol. Řizeni ve vécech rodinněprávních v České republice, Slovenské republice a Nèmecku a jejïch aktuálni problémy. 1. vyd. Praha: Leges, s. r. o., 2010, s. 96.

40 PARASHAR, Archana a Francesa DOMINELLO. The Family In Law. 1. vyd. Melbourne: Cambridge University Press, 2017, s. 295.

41 SHEEHAN, Rosemary, Allan BOROWSKI a kol. Australia's Childern's Courts Today and Tomorrow. 1. vyd. Victoria, Australie: Springer, 2013, s. 37.

42 MORAG, Tamar. Children's Rights in Israeli Case Law: A Spiral Progression. In: Israel Studies Review, Winter, New York: Berghahn Books, 2013, roč. 28, č. 2, s. 282-299.

43 Tyto informace jsou čerpány z oficiálních webových stránek izraelského ministerstva spravedlnosti. Dostupné z: https://www.justice.gov.il/En/Units/LegalAid/ResponsibilityAreas/SubjectResponsibility/ Pages/CHILDREN\%20AND\%20YOUTH.aspx [cit. 7. 3. 2021]. 
ochraně participačních práv dítěte ve smyslu Úmluvy. Dítěti je totiž dle jeho názoru poskytnuta nejen ochrana jeho práv odborníkem, ale současně je mu v řízení po celou dobu po boku osoba, na kterou se může kdykoli obrátit a jejíž povinností je věnovat pozornost názoru dítěte a tento před soudem prezentovat. Zástupci jsou povinni absolvovat pravidelná školení a vzdělávat se také v oblasti komunikace s dítětem.

Jsem přesvědčena, že zavedení podobné funkce v českém právním řádu a s tím spojená systémová změna kolizního opatrovnictví by vedla nejen ke zvýšení standardu ochrany procesních (a jejich prostřednictvím i hmotněprávních) práv nezletilých účastníků rrízení, ale také ke snížení stávající zátěže kladené výhradně na soud. Kolizní opatrovník by měl mít právní vzdělání doplněné alespoň o základy dětské psychologie či pedagogiky. U takto vzdělané osoby lze předpokládat, že bude skutečně schopna s dítětem pracovat, zjistit jeho názor, vysvětlit mu všechna jeho práva a povinnosti.

Na takovou osobu by také měla být zákonem přenesena odpovědnost za zajištění všech těchto úkolů. Napříště by tak tato odpovědnost nemusela být na soudci. Soudce by však měl nést odpovědnost za zajištění účinného zastoupení v prrípadech, kdy je to vhodné. Jmenování speciálního opatrovníka dítěti by totiž nemělo být dle mého názoru nutné v každém řízení. Například je-li dítě ve věku, kdy prozatím není schopno formulovat svůj názor, je zcela dostatečná účast OSPOD jako garanta nejlepšího zájmu dítěte ${ }^{44}$.

\section{Závěr}

Tento článek byl věnován problematice participačních práv dítěte v civilním soudním řízení, tedy otázce práva dítěte zúčastnit se rrízení, které se ho týká. Jedná se o téma, které je v posledních letech často skloňováno jak odbornou tak laickou veřejností, a se kterým se často vypořádává také Ústavní soud. Jednou z nejdůležitějších složek participačních práv dítěte, nebo možná odrazem participačních práv dítěte, je právo dítěte být slyšeno a vyjádřit svůj názor.

Právo dítěte být slyšeno a právo, aby bylo k jeho názoru přihlíženo, je jedno z velmi důležitých práv, které výrazně posiluje právní postavení dítěte ${ }^{45}$, nebot' dítěti umožňuje v míře odpovídající jeho vyspělosti podílet se na rozhodování o záležitostech, které se ho týkají. V judikatuře Ústavního soudu lze sledovat nepochybnou snahu naplňovat

44 Za předpokladu, že nedostatečnost zastoupení nezletilého prostřednictvím OSPOD nevyplývá z jiných okolností kauzy. Pokud by se mělo jednat např́klad o nestandardně složité řízení ve věcech péče soudu o nezletilého, je určitě namístě jmenování speciálního opatrovníka i dítěti, které není schopno své názory formulovat. Hledání nejlepšího zájmu nezletilého bude mnohdy spočívat ve vyřešení složitých právních otázek, které pomohou rozklíčovat spory mezi rodiči. V takových př́padech se v praxi zcela jasně projevuje, že OSPOD není schopen poskytnout právům dítěte dostatečnou ochranu, nebot' mu chybí jednak právní vzdělání a současně jednoduše nemá dostatečný časový prostor, když kolizní opatrovnictví je jednou z činností OSPOD.

45 HRUŠÁKOVÁ, Milana, Zdeňka KRÁLÍČKOVÁ a Lenka WESTPHALOVÁ. Občanský zákoník II. Rodinné právo (』 655-975). Komentár. 1. vyd. Praha: C. H. Beck, 2014, s. 852. 
principy nejlepšího zájmu dítěte, a to mimo jiné prostřednictvím širokého práva být slyšeno vztahujícího se opravdu na všechna řízení, která mohou ovlivnit právní poměry dítěte ${ }^{46}$.

V souvislosti se slyšením nezletilého v soudním řízení jsou však naprosto nepochybně kladeny obrovské požadavky na osobu soudce, který je i v duchu aktuální judikatury Ústavního soudu zodpovědný za efektivní realizaci práva dítěte být slyšeno, a to vč. všech atributů, které toto právo zahrnuje (tj. včetně práva dítěte, aby mu byly poskytnuty informace nezbytné $\mathrm{k}$ tomu, aby si mohlo utvořit svůj názor, práva dítěte na to, aby se dozvědělo, jakým zpơsobem bylo v řízení rozhodnuto atd.). Při přímém slyšení dítěte soudcem je také nezbytné, aby tento byl schopen s dítětem skutečně promluvit, nebot' hovor s dítětem vždy nemusí probíhat tak, jako s dospělým člověkem. Soudce by měl mít ideálně i základy psychologického nebo pedagogického vzdělání, což jsou samozřejmě mimoprávní znalosti a schopnosti.

I tyto závěry mě vedou k názoru, že de lege ferenda je nezbytné uvažovat o systémové změně pojetí zastoupení nezletilého v civilním soudním řízení, a to nejlépe po vzoru německé, australské či izraelské úpravy zavedením nové procesní funkce - zástupce (opatrovníka) dítěte, který by měl mít př́islušené vzdělání, a jehož úkolem by měla být primárně ochrana zájmů dítěte a reprezentace jeho názorů v ř́zení, a s tím související také práce s nezletilým (poskytování informací o řízení, o výsledku řízení, vysvětlení jednotlivých procesní fází, důsledků jednotlivých procesních kroků apod.).

46 Ústavní soud aktuálně např́klad dovodil právo nezletilého vyjádřit se ke změně svého př́imení (srov. nález Ústavního soudu ze dne 22. 10. 2019, sp. zn. IV. ÚS 1002/19). 